\title{
FILOSOFI MAKNA ADIL DALAM PERNIKAHAN POLIGAMI
}

\author{
Iim Fahimah \\ Fakultas Syariah IAIN Bengkulu \\ Jln. Pagar Dewa Kota Bengkulu \\ iimfahimah@iainbengkulu.ac.id \\ Wahyu Abdul Jafar \\ Fakultas Syariah IAIN Bengkulu \\ Jln. Pagar Dewa Kota Bengkulu \\ wahyujabar@iainbengkulu.ac.id
}

\begin{abstract}
This study explains in detail the question of fair meaning in polygamy marriages. So far, the meaning of fair is always different from everyone. Therefore, there is a need for a comprehensive study to decipher the issue of the meaning of scientific fairness. Substantive justice in Islam is always associated with the maker of the syara' (Allah). In relation to polygamy, The fair is a condition for a man to be allowed to do polygamy. justice aspects in polygamy is not an easy thing to do. Islam does not forbid or encourage let alone rule polygamy, this is because polygamy is a behavior that has existed since the time of ignorance and then tightened requirements in Islam. Islam is very strict in giving conditions until it is almost said not to be, because the argument contained in the Al Qur'an, maybe on fair terms but followed by another verse which says that "will not be able to act justly despite trying as much as possible" Although in the end the scholars agreed that it was fair qualitatively humans will not be able to, so ,in the end the scholars agree that what is meant is the minimum limit that
\end{abstract}


can be done to do justice, namely turn time, income and shelter.

\section{Keywords: Fair, Philosophy, Marriage, Polygamy}

\section{Pendahuluan}

Adil dan keadilan menjadi keinginan bagi jiwa yang bersih dan dirindukan oleh segenap jiwa yang sadar, sementara suasana dan aplikasi dari sebuah keadilan itu juga diharapkan oleh semua manusia. Oleh karena itu, pelaku-pelaku kebijakan hendaknya adil dalam bertindak dan mengambil keputusan. al-Quran memberikan perintah keras agar keadilan ditegakkan di segala bidang kehidupan disertai dorongan yang kuat supaya setiap insan menjadi anggota barisan penegak dan pembela keadilan. Allah memerintahkan kita untuk berbuat adil, berbuat baik dan menjauhi kemungkaran dan permusuhan. Begitu pula bagi para pelaku poligami hendaknya mengerti dan mengaplikasikan syarat mutlak yang diperintahkan Allah agar tidak terjadi kezaliman, kemungkaran dan permusuhan. Oleh karena pentingnya "adil" dalam berbagai aspek kehidupan termasuk dalam berpoligami, maka penulis akan membahas tentang filsafat hukum Islam tentang adil sebagai syarat dalam berpoligami dalam hal ini Penulis memaparkan Pengertian adil dan dan dasar poligami, Konsep adil menurut Islam, Pandangan Ulama tentang adil dalam berpoligamai serta Implementasi adil menurut Fuqaha.

\section{Pembahasan}

\section{Pengertian Adil Dan Dasar Hukum Poligami}

Adil dalam kamus bahasa Indonesia berarti: Sama rata, berpihak kepada yang benar, berpegang pada kebenaran, sepatutnya dan tidak sewenang wenang ${ }^{1}$. Adil dalam bahasa Arab berasal dari kata Adalah, mu'adalah lafazh yang menuntut persamaan, persamaan ini dalam berbagai macam. ${ }^{2}$ Dalam kamus besar bahasa Indonesia dijelaskan bahwa poligami adalah system perkawinan yang salah satu pihak memiliki atau mengawini beberapa lawan jenisnya dalam waktu yang bersamaan. ${ }^{3}$ Sedangkan menurut para fuqaha, poligami adalah menikahi wanita lebih dari satu. Adapun yang menjadi dasar hukum poligami adalah firman Allah: Dalam kamus besar bahasa Indonesia dijelaskan bahwa poligami

\footnotetext{
1.Pusat Bahasa Departemen pendidikan nasional, Kamus besar bahasa Indonesia, balai pustaka, Edisi ke3, cet kelima tahun 2008, 8

2 Abi qasim Husein, Mu'jam mufradat alfaz̧h al-Quran, (Beirut: Dar al-kutub al-ilmiyah, 2004), Cet 1, 363.

3 Tim Redaksi, Kamus Besar Bahasa Indonesia, Jakarta: Pusat Bahasa Departemen Pendidikan Nasional Balai Pustaka, th. 2000), 885
} 
adalah sistem perkawinan yang salah satu pihak memiliki atau mengawini beberapa lawan jenisnya dalam waktu yang bersamaan. ${ }^{4}$ Sedangkan menurut para fuqaha, poligami adalah menikahi wanita lebih dari satu. Poligami menurut kamus bahasa Indonesia artinya: Sistem perkawinan yang salah satu pihak memiliki atau mengawini beberapa lawan jenisnya diwaktu yang bersamaan ${ }^{5}$. Kata poligami dan adil adalah dua kata yang tidak bias dipisahkan, karena tuntutan bagi pelaku poligami adalah adil. Allah berfirman dalam surat An Nahl [16]: 90:

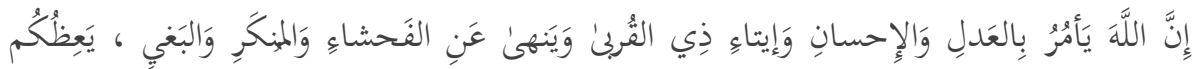
لَعَلَّكُمْ تَذَكَُّورنَ

Dalam surat QS. an-Nisa [4]: 129:

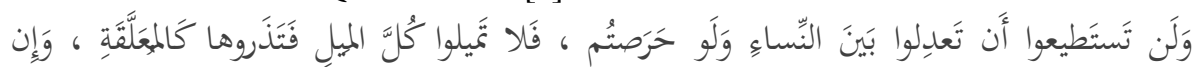
تُصلِحوا وَتَتَّقوا فَإِنَّ اللَّة كانَ غَفورًا رَحيمًا

Yang dimaksud dengan pembagian yang seadil adilnya pada ayat diatas adalah dalam hal pembagian giliran dan pembagian nafkah. Nafkah sendiri meliputi biaya hidup (nafaqah) pakaian (kiswah) dan tempat tinggal (maskan) ${ }^{6}$. Hal ini di dukung oleh Firman Allah dalam surat alBaqarah [2]: 228:

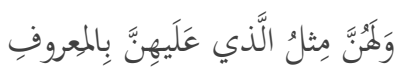

Adapun yang menjadi dasar hukum poligami adalah QS. an-Nisa [4]: 3:

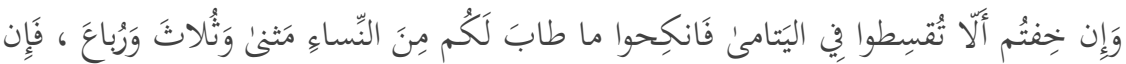

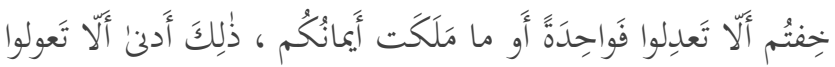

Dalam sistem perundang-undangan di Indonesia, negara yang menetapkan ketentuan yang ketat untuk poligami. UU No. 1 Th. 1974 pasal 3 ayat (2) dijelaskan bahwa seorang suami diperbolehkan beristeri lebih dari seorang apabila dikehendaki oleh pihak-pihak yang bersangkutan dan mendapat izin dari pengadilan.

\footnotetext{
${ }^{4}$ Ibid.

${ }^{5}$ Ibid, 885

${ }^{6}$ Sykh Abu bakar Syakho al-Dimyathi, I'anatuthalibin, Vol III, (Beirut, Daral-fikr, 2002), 421
} 
Adapun alasan-alasan yang dijadikan pedoman oleh pengadilan untuk memberi izin poligami ditegaskan pada pasal 4 ayat (2), yaitu: 1) isteri tidak dapat menjalankan kewajibannya sebagai isteri; 2) isteri mendapat cacat badan atau penyakit yang tidak dapat disembuhkan; dan 3) isteri tidak dapat melahirkan keturunan.

Ketentuan seperti ini juga ditegaskan dalam PP No. 9 tahun 1975 pasal 41 huruf a dan KHI pasal 57. Pasal 5 UU Perkawinan menetapkan syarat-syarat poligami sebagai berikut: 1) adanya persetujuan dari isteri/isteri-isteri; 2) adanya kepastian bahwa suami mampu menjamin keperluan-keperluan hidup isteri-isteri dan anak-anak mereka; 3) adanya jaminan bahwa suami akan berlaku adil terhadap isteri-isteri dan anakanak mereka. Di samping ketentuan ini UU Perkawinan juga mengatur prosedur yang harus ditempuh suami dalam melakukan poligami, yakni melalui proses di pengadilan ${ }^{7}$.

Secara sosiologis, poligami dibolehkan karena telah dikenal dan dilaksanakn oleh penganut berbagai syariat agama serta adat istiadat masyarakat sebelum turunnya ayat ayat ini, praktek ini biasa dilakukan dengan banyak istri yang tidak terbatas, kemudian setelah Islam datang membatasi kebolehan dengan empat saja ${ }^{8}$. Secara Filosopis kebolehan poligami dengan batasan maksimal empat, itu hanya toleransi dari kebiasaan lama yang tidak beraturan dan tidak terbatas dalam berpoligami. Secara psikologis, tidak mungkin kebiasaan jahiliyah yang sudah mengakar kuat kemudian dilarang secara spontan tanpa berangsurangsur. Secara ekonomis, laki-laki yang dibolehkan berpoligami adalah yang mampu memberikan nafkah kepada istri-istrinya. ini berarti dengan dibolehkannya poligami seharusnya ada penyelesaian masalah ekonomi bagi pihak tertentu.

\section{Konsep Adil Dalam Islam}

Diskursus mengenai keadilan dapat dilacak pada sumber-sumber hukum Islam, seperti Alquran dan hadis. Alquran dalam beberapa bagiannya memerintahkan umat Islam untuk berbuat adil. Surat an-Nisa ayat 58 menyatakan bahwa dalam mengadili dua orang yang bersengketa harus dilakukan secara adil. Surat al-Maidah ayat 6 memerintahkan orang-orang mukmin berbuat adil karena adil lebih dekat pada ketaqwaan. Kutipan ayat Alquran tersebut memberikan penerangan bahwa keadilan menjadi sebuah nilai yang dijunjung tinggi dalam ajaran

\footnotetext{
${ }^{7}$ H. Abdul manan, dan M. Fauzan, Pokok-pokok bukum perdata wewnang peradilan Agama, (PT Raja grafindo Persada, cet V, th 2002), 190

${ }^{8}$ M.Quraish Shihab, tafsir al-Misbah, (Jakarta: lentera hati, volume II tt), 410

${ }^{9}$ Khairudin Nasution,Status wanita di Asia tenggara, (Jakarta : INIS cet 1, 2002), , 109 
Islam. Meskipun demikian, pemahaman mengenai keadilan adalah sebuah persoalan tersendiri bagi para pemikir muslim. Sebagian pemikir muslim mendefinisikan keadilan dalam kerangka filsafat Aristotelian. Keadilan dipahami sebagai pengejawantahan keutamaan yang tertinggi. Keadilan adalah keutamaan yang ada dalam jiwa manusia setelah kualitaskualitas utama lain, yaitu hikmah (kebijaksanaan), iffah (kesucian diri), dan syaja'ah (keberanian) terpenuhi. Kualitas-kualitas hikmah, iffah, dan syaja'ah terwujud melalui penyeimbangan dua titik ekstrim kualitas manusia. Syaja'ah, misalnya, adalah jalan tengah dari kualitas pengecut dan kemarahan yang tidak terkendali ${ }^{10}$.

Konstruksi nalar Islam tentang hukum dan keadilan dapat dijumpai dalam Alquran dan hadis. Alquran mengandung beberapa istilah yang dekat dengan istilah keadilan, yaitu al-qisth, al-adl, dan mizan. Kata adl merujuk kepada keadilan dalam pengertian balasan atau retribusi yang sama. Dimisalkan, jika ada orang yang tidak melaksanakan puasa, maka ia harus mengganti pada hari lain. Semantara itu, kata qisth merujuk kepada kesamaan dalam pengertian pemberlakuan aturan kepada orang-orang yang bukan warga negara. Pengertian keadilan dalam kata qisth mengandung konflik kepentingan, sementara adl mengandung keseimbangan kepentingan antar kelompok. Mengenai kata mizan dalam Alquran merujuk kepada pengertian keseimbangan (balance) ${ }^{11}$ Muhammad Thahir Azary menjabarkan pengertian keadilan dalam Alquran pada ranah politik. Penjelasannya mengenai ayat-ayat keadilan dalam Alquran didasarkan kerangka bahwa keadilan menjadi prinsip ketiga dalam nomokrasi. ${ }^{12}$ Keadilan dalam Islam menurut Azhary identik dengan kebenaran. Kebenaran dalam konteks ajaran Islam dihubungkan dengan Allah sebagai sumber kebenaran, yang dalam Alquran disebut dengan al-haqq. Kata adl dalam Alquran menurut Azhary secara bahasa berarti sama. Kata adl menunjukan keseimbangan atau posisi tengah ${ }^{13}$.

Quraish Shihab memetakan pengertian keadilan yang dipahami oleh para ulama dengan empat pengertian. Pertama, keadilan yang berarti sama yang didasarkan atas surat an-Nisa ayat 4. Kata adil dan keadilan dalam pengertian pertama tersebut berkenaan dengan sikap hakim dalam proses pengambilan keputusan. Kedua, keadilan berarti seimbang, yang

\footnotetext{
10 Ibnu Maskawaih, Tabdhib al-Akblaq wa Tathhir al-'Araq, (Mesir: Matba'ab Husayniyyah, tt), 10-24

${ }^{11}$ Quraish Shihab, Wawasan Alquran, Tafsir Maudhui atas berbagai Persoalan Umat, (Bandung: Mizan, 1996), 112.

12 Lihat Muhammad Tahir Azhary, Negara Hukum: Suatu Studi tentang Prinsipprinsipnya Dilihat dari Segi Hukum Islam, Implementasinya pada Periode Negara Madinah dan Masa Kini, (Jakarta: Bulan Bintang, 1992), 66.

${ }^{13}$ Ibid.
} 
identik dengan proporsional dalam segala hal. Ketiga, adil juga berarti memberikan perhatian kepada hak-hak individu dan memberikan hakhak kepada pemiliknya. Keadilan dalam pengertian ketiga itu berkaitan dengan konteks sosial. Adil dalam pengertian keempat dinisbatkan kepada Allah. Keadilan dalam pengertian keempat berarti memelihara kewajaran dan kelangsungan eksistensi. ${ }^{14}$ Keadilan dalam hukum Islam selalu dikaitkan dengan aspek Ketuhanan, yaitu dalam hubungan antara manusia dengan Tuhan dan antara manusia dengan manusia dalam perspektif wahyu. Yurisprudensi Islam menghasilkan satu konsep besar hukum yang memayungi dan memberi pengertian terhadap pola kerja hukum Islam. Konsep tersebut adalah maslabah. Istilah maslahah dalam kajian hukum Islam dipakai dalam dua pengertian, yaitu maslahah mursalah dan maslahah sebagai maqasid syari'ah. Maslahah menurut pengertian pertama (maslahah mursalab) adalah salah satu upaya menggali hukum dengan didasarkan kepada pertimbangan kebaikan umum. Maslabah mursalah sebagai sebuah metode penggalian hukum mula-mula diasosiasikan dengan mazhab Maliki, namun dalam perkembangannya metode maslahah digunakan secara luas untuk memecahkan masalahmasalah yang tidak ada petunjuk ekplisitnya dari Alquran dan hadis.

Pengertian maslahah sebagai maqasid syari'ab dikembangkan oleh alJuwayni ${ }^{15}$ yang kemudian dielaborasi lebih lanjut oleh al-Ghazali dan mencapai puncaknya dalam pemikiran as-Syathibi. Maslabah dalam pengertian maqasid syari'ah menekankan kepada tujuan-tujuan esensial yang ingin dicapai oleh hukum Islam. Tujuan-tujuan esensial syariah tersebut diklasifikasikan menjadi tiga, yaitu memelihara kepentingan manusia yang bersifat primer (dharury), sekunder (haijy) dan suplementer (tabsiny). Kepentingan manusia yang bersifat primer tercakup dalam alkulliyah al-khamsah, yaitu memelihara agama (hifdzud diin), memelihara jiwa (bifdzun nafs), memelihara akal (bifdzul 'aq), memelihara keturunan/kehormatan (bifdæun nasl) dan memelihara harta (bifdzul mal). Rumusan tersebut dipandang berasal dari nilai-nilai ajaran hukum

\footnotetext{
${ }^{14}$ Quraish Shihab, Opcit., 114-116.

15 Al-Juwayni membagi maslahah menjadi lima tingkatan. Pertama, dharury, yaitu kebutuhan-kebutuhan mendasar bagi manusia. Kedua, al-hajat al amah (kebutuhan umum), yang sebenanya hampir sama dengan dharury tetapi dari tingkat kebutuhan masih di bawah dharury. Ketiga, mukarromah, yaitu hal-hal yang terkait dengan keutamaan, seperti kebersihan. Keempat, hampir sama dengan yang ketiga dengan prioritas lebih rendah dari yang ketiga. Tingkatan keempat mencakup hal-hal yang patut dipuji/dihargai, seperti mencatat kontrak dan pembebasan budak. Kelima, tingkatan yang sebenarnya kurang jelas dan hanya didefinisikan sebagai hal-hal yang tidak termasuk dalam empat tingkatan sebelumnya. Contohnya adalah ibadah fisik murni. Lihat dalam Muhammad Khalid Masud, Shatibi's Philoshopy of Islamic Law, (Delhi: Adam Publisher, 1997), 138.
} 
Islam. ${ }^{16}$ Hubungan antara maslahah dan keadilan memang tidak mudah dipahami apabila hal tersebut tidak dihubungankan melalui aspek teologis yang membangun paradigma hukum Islam. Kalangan Mu'tazilah mengajukan kebaikan umum sebagai inti ajaran hukum Islam, yang di dalamnya mengandung nilai keadilan dan maslabah sekaligus. Akan tetapi, meskipun diakui sebagai sesuatu yang dikandung hukum Islam, keadilan sebagai sebuah pembahasan hukum akan sulit dijumpai kitab-kitab ushul fiqh. Ushul fiqh (yurisprudensi Islam) memberikan petunjuk mengenai hubungan Tuhan dengan manusia, posisi Tuhan sebagai pemberi hukum dan berbagai kaedah yang menjabarkan bagaimana kehendak Tuhan dalam Alquran dan penjelasan Nabi.

Keadilan dalam penjelasan tersebut masuk dalam kategori hukum substantif. Keadilan didefinisikan dalam sudut pandang teologis, hubungan Tuhan dengan manusia bersifat vertikal. Allah sebagai Maha Adil dan Maha Benar lebih mengetahui kebenaran dan keadilan hakiki. Manusia harus selalu menemukan keadilan dan kebenaran yang dianugerahkan Tuhan melalui proses ijtihad. Prinsip keadilan meniscayakan penggunaan rasio untuk membuat perbandingan antara satu kasus yang tidak diterangkan oleh Firman Allah atau sabda Nabi dengan kasus lain yang telah memiliki legitimasi hukum. Dengan cara itu, hukum Islam berkembang dan menjangkau kasus-kasus hukum yang lebih luas berdasarkan prinsip persamaan. Teori-teori hukum Islam memang tidak memilah secara tegas antara hukum positif dan moralitas. ${ }^{17}$ Konstruksi nalar Islam tentang hukum dan keadilan merepresentasikan pandangan yang mengaitkan keadilan dengan kebenaran. Bertindak adil adalah bertindak secara benar. Mencari keadilan sama dengan mencari kebenaran. Kebenaran adalah representasi dari kehendak Tuhan kepada manusia yang dijabarkan melalui al-abkam al-khamsah, yaitu wajib, sunnah, mubah, makruh, dan haram. Keadilan substansif dalam hukum Islam selalu dikaitkan dengan kehendak pembuat syara'(Allah) terhadap manusia, baik kehendak tersebut dipahami melalui deduksi logis (kaedah lughawiyyah), deduksi analogis (qiyas), atau deduksi dari kaedahkaedah umum syariah (maqasid syari'ah). ${ }^{18}$

Pada akhirnya, keadilan mengacu pada upaya hakim untuk menemukan kebenaran dan memberikan hukum jika ada pelanggaran

16 Ibid., 152.

17 Keadilan sebagai sebuah nilai moral memiliki ciri khas karena watak tuntutan moralnya yang berbeda dengan tuntutan moral lain. Moralitas keadilan selalu terkait dengan manusia satu dengan manusia lain berdasarkan ukuran perbandingan dalam pemberian perlakuan oleh otoritas publik. Lihat Manzoor Ahmad, Morality and Law, (Karachi: Asia Publshers, 1986), h. 119.

18 ] Abdul Wahhab Khallaf, Ushul Fiqh. (Beirut: Dar al-Qalam, 1978), 105-112. 
yang tidak ada aturan tegasnya secara formal. Hal tersebut adalah bentuk dari keadilan prosedural. Keadilan prosedural adalah aspek ekternal hukum, tempat keadilan substantif direalisasikan. Tanpa adanya keadilan secara prosedural, keadilan substantif hanya akan menjadi teori-teori yang tidak menyentuh realitas masyarakat. Meskipun demikian, selain keadilan, nilai kepastian dan kemanfaatan hukum juga penting untuk dipertimbangkan dalam penegakan hukum ${ }^{19}$.

\section{Pandangan Ulama Tentang Adil Dalam Poligami}

Menurut Imam Syafi'i, Hanafi, Maliki dan Hambali berpendapat bahwa seorang suami boleh memiliki istri lebih dari satu, karena dalam agama Islam seseorang laki-laki dibolehkan mengawini lebih dari satu tetapi dibatasi hanya sampai empat orang istri. Akan tetapi kebolehannya tersebut memiliki syarat yaitu berlaku adil antara perempuan-perempuan itu, baik dari nafkah atau gilirannya ${ }^{20}$ Muhamad Rasyid Ridla dalam Tafsir Al-Manar Juz 4 mengatakan bahwa boleh poligami karena faktor-faktor yang membolehkan poligami itu adalah darurat menurut ukuran kadar kebutuhan sedangkan golongan pria umumnya terdorong melakukan poligami ini untuk memuaskan nafsu saja bukan karena kemashlahatan sedangkan kesempurnaan yang menjadi prinsip tujuan adalah monogamy, dijadikanlah poligami di dalam Islam itu selaku Rukhshah bukan selaku kewajiban dan bukan pula selaku hal yang disunnatkan menurut esensinya dan diikatlah dengan syarat yang dijelaskan oleh ayat Al-Quran secara tegas dan berulang-ulang, maka perhatikanlah.... ${ }^{21}$

Cukup beristeri satu apabila mereka tidak sanggup berlaku adil sebagaimana hal ini menjadi kenyataan sejalan dengan kewajiban mereka mengamalkan nash ayat (apabila kamu khawatir tidak berlaku adil maka hendaklah kamu beristeri seorang saja) dan adapun ayat (maka nikahilah wanita yang baik bagimu) maka ia dikaitkan dengan ayat (maka jika kamu tidak dapat berlaku adil) tersebut. Memperhatikan terlebih dahulu sebelum melakukan poligami tentang kewajiban mereka menurut syara' yaitu mengenai keadilan, memelihara kerukunan antara anak-anak dan memelihara isteri-isteri dari kemelaratan hidup yang membawa mereka kepada perbuatan yang tidak layak. Poligami itu bertentangan dengan hukum asli dan bertentangan dengan kesempurnaan serta meniadakan ketenangan jiwa, kesantunan dan kasih sayang yang menjadi rukun kehidupan suami-isteri,tidak ada beda antara perkawinan orang yang

${ }^{19}$ Lihat Theo Huijbers, Filsafat Hukum dalam Lintasan Sejarah, (Yogyakarta: Kanisius, 1993), 161.

${ }^{20}$ Imam Muhammad al-Syaukani, Fathu al-qadir Vol I, (Kairo: Dar al-Hadis, tt) 563.

${ }^{21}$ Muhammad Rasyid Ridla, Tafsir al-Manar Vol IV, (Beirut : Dar al-ma'rifah, t), 357-358

8 Iim Fahimah \& Wahyu Abdul Jafar - Filosofi makna adil dalam pernikahan poligami 
hancur kehidupan rumah tangganya dengan hewan. Maka tidaklah layak bagi orang Muslim melakukan poligami kecuali karena darurat serta berpegang teguh dengan sesuatu yang disyaratkan oleh Allah swt. yaitu berlaku adil. Tingkatan adil di bawah tingkatan ketentaraman diri, sopan santun dan kasih sayang dan tidak ada dibelakang keadilan itu kecuali kezhaliman seseorang terhadap dirinya, terhadap isterinya, terhadap anaknya dan bangsanya dan Allah tidak suka kepada orang-orang yang zhalim $^{22}$

Menurut Musthafa al-Maraghi Dalam Tafsir Al-Maraghi kebolehan poligami adalah kebolehan yang dipersulit dan diperketat. Menurutnya, poligami diperbolehkan dalam keadaan darurat yang hanya dapat dilakukan oleh orang orang yang benar-benar membutuhkan. Dia kemudian mencatat kaidah hukum Islam "Dar'u al-mafasid muqaddamun 'ala jalbi al-mashalib" (menolak yang berbahaya harus didahulukan daripada mengambil yang bermanfaat). Catatan ini dimaksudkan untuk menunjukkan betapa pentingnya untuk berhati-hati dalam melakukan poligami. Alasan yang membolehkan poligami, menurut al-Maraghi, adalah: 1) karena isteri mandul sementara keduanya atau salah satunya sangat mengharapkan keturunan; 2) apabila suami memiliki kemampuan seks yang tinggi sementara isteri tidak mampu meladeni sesuai dengan kebutuhannya; 3) jika suami memiliki harta yang banyak untuk membiayai segala kepentingan keluarga, mulai dari kepentingan isteri sampai kepentingan anak-anak; dan 4) jika jumlah perempuan melebihi jumlah laki-laki yang bisa jadi dikarenakan perang. Atau banyaknya anak yatim dan janda sebagai akibat perang juga membolehkan dilakukannya poligami. Terkait dengan QS. al-Nisa' [4]: 129 al-Maraghi mencatat, yang terpenting harus ada upaya maksimal suami untuk berbuat adil ${ }^{23}$.

Kebolehan Poligami, mereka sangat tekankan kepada syarat adil sebagai syarat muthlak atas dasar pandangan mereka bahwa ayat فَنْكِحُوا مَا

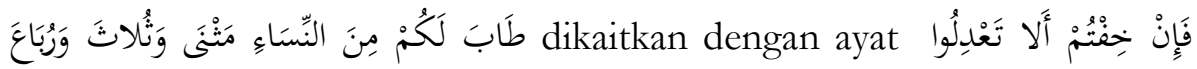

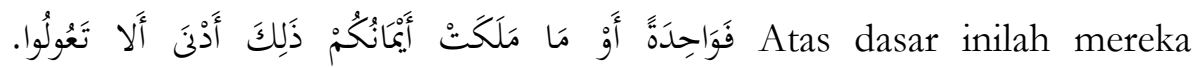
berpendirian bahwa melakukan poligami itu hukumnya dilarang. Hukum larangan ini mereka ambil dari fi'il amr yang tersirat yang menjadi jawab

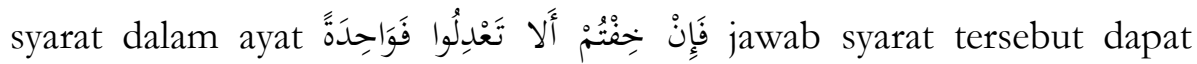
الآمر بالشئ هى عن atas dasar kaidah فانكحوا واحدة atau فلتزموا واحدة berbentuk

\footnotetext{
${ }^{22}$ Muhammad Rasyidla,Ibid, 360-370

${ }^{23}$ Ahmad Musthafa al-Maraghi, tafsir al-Maraghi, (Mesir, Syirkah maktabah wamathba'ah musthafa al- baby al-halabi wa auladihi, Vol 4, 1969), 181-182
} 
ضد yang artinya perintah melakukan sesuatu artinya larangan terhadap meninggalkan sesuatu. Mereka tafsirkan ayat tersebut sebagai berikut: فَإٍٍِ Artinya jikalau kamu khawatir akan tidak berlaku adil maka janganlah kamu menikahi lebih dari seorang wanita." ${ }^{24}$

Menurut Quraish Shihab dalam tafsir al-Misbah penyebutan dua tiga atau empat dalam ayat tersabut pada hakikatnya adalah dalam rangka berlaku adil pada anak yatim. Redaksi pada ayat ini mirip dengan seorang yang melarang orang lain makan makanan tertentu, dan untuk menguatkannya larangan itu dikatakannya : "jika anda khawatir makan makanan ini, habiskan saja makanan selain yang ada dihadapan anda." Tentu saja, perintah untuk menghabiskan makanan lain itu hanya sekedar menekankan perlunya mengindahkan larangan untuk tidak makan makanan tertentu itu ${ }^{25}$.

\section{Implementasi Adil Dalam Poligami Menurut Fuqaha}

Mayoritas ulama fiqh menyadari bahwa keadilan kualitatif adalah sesuatu yang sangat mustahil bisa diwujudkan. Abdurrahman al-Jaziri menuliskan bahwa mempersamakan hak atas kebutuhan seksual dan kasih sayang di antara istri-istri yang dikawini bukanlah kewajiban bagi orang yang berpoligami karena sebagai manusia, orang tidak akan mampu berbuat adil dalam membagi kasih sayang dan kasih sayang itu sebenarnya sangat naluriah. Sesuatu yang wajar jika seorang suami hanya tertarik pada salah seorang istrinya melebihi yang lain dan hal yang semacam ini merupakan sesuatu yang di luar batas kontrol manusia ${ }^{26}$. Menurut penulis, dengan adanya ayat yang menyatakan tidak akan mampu kalian berbuat adil, itu artinya larangan dari Allah bagi para suami untuk melakukan poligami selama istri masih bisa memenuhi kebutuhan suami secara biologis. Karena keadilan kualitatif sulit untuk direalisasikan maka ulama memberikan batas ninimal adil

\section{Adil dalam pembagian giliran.}

Salah satu pembagian yang penting dilakukan oleh suami terhadap para istrinya, ialah pembagian giliran, jika ia bekerja siang hendaklah ia mengadakan giliran pada waktu malam begitu pula sebaliknya, apabila ia bekerja malam hendaklah ia melakukan giliran pada waktu siang (QS. anNisa [4]: 19)

\footnotetext{
24 Abi Ja'far Muhammad Jarir At-Thabari, Tafsir a-Thabari Vol 3, (Kairo: Maktabah tauqifiyah, 2004), 248

${ }^{25}$ M.Quraish Shihab, Opcit, 410

26 Abdurrahman Al-jaziri, Kitab al-figh a'la madzabib al-arba'ah, Vol IV, (Beirut, Dar alkutub al-ilmiyah, tt), 213.
}

10 Iim Fahimah \& Wahyu Abdul Jafar - Filosofi makna adil dalam pernikahan poligami 


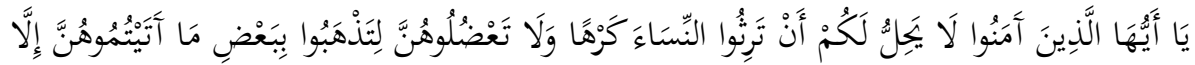

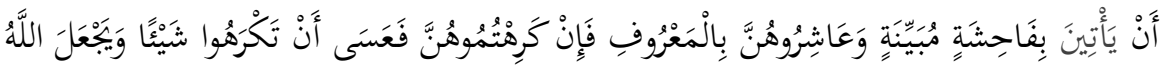 فِيدِ خَيْرًا كَثِيرًا}

Apabila sedang dalam giliran seseorang maka haram hukumnya bagi seorang suami mendatangi yang lain yang bukan gilirannya, kecuali kalau ada kepentingan yang sangat darurat, seperti istri sakit keras atau sedang dalam bahaya dll. Apabila demikian maka seorang suami dibolehkan masuk ke rumah istri yang bukan gilirannya. ${ }^{27}$

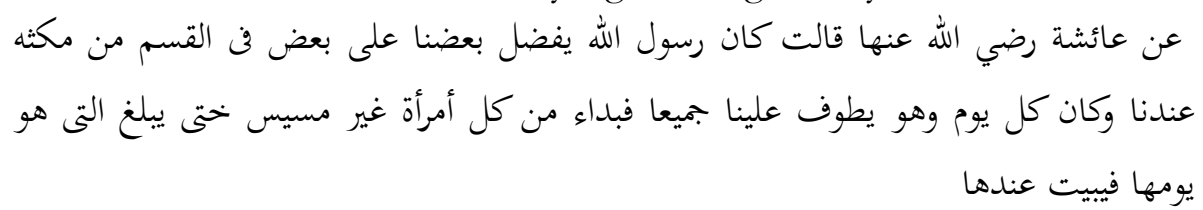

Artinya: Dari Aisyah rasulullab $S A W$ tidak melebihkan sebagian kami diantara yang lain dalam pembagian waktu untuk kembali pada yang lain, sekalipun sedikit sekali waktu bagi Rasululah, beliau tetap bergilir beliau tetp bergilirkepada kami dan didekatinya tiap tiap istrinya yang mendapat gilirannya, lalu Ia bermalam di rumabnya. (HR. Abu Dawud dan Ahmad)

عن انس رضي الله عنه قال كان النبي ص م يطوف على نسائه قى الليلة الواحدة وله يومئذ تسع نسوة

"Dari Anas R.A. Ia berkata Nabi bergilir pada istri-istrinya pada suatu malam,dan ketika itu ada 9 istri

Kedua kerterangan hadis di Atas, atas dasar merelakan antara istri dan itri-istri lainnya, kejadian ini diantara istri-itri Nabi sehingga tidak mungkin terjadi perselisihan antara mereka ${ }^{28}$ Seorang suami hanya untuk keperluan seperti mengambil barang dagangan kalau kejadiannya seperti itu maka ketika suami lalai tidak memenuhi hari yang seharusnya untuk giliran istri tersebut maka seorang suami tadi harus mengqadla.Berbeda pendapat dengan keterangan di atas yang mengatakan harus mengqadla, giliran jika jika memasuki rumah istri pada siang hari padahal bukan

\footnotetext{
27 Syekh Nawawi al-Bantani, Nihayah al-Zein, (Surabaya, al-hidayah, tt0, 316

${ }^{28}$ Ibnu Masud dan Zaenal Abidin, Fiqih madzhab Syafii, edisi lengkap buku 2 (ttp; CV pustaka setia. 2007), 331
} 
gilirannya, lantaran karena ada keperluan, waktu siang bukanlah waktu pokok (waktu yang tidak tenang.) ${ }^{29}$

Sunnah menyamaratakan dalam berbagai istimta' dan suami tidak mendapatkan sangsi lantaran kecodongan hatinya pada salah seorang istrinya, menyamaratakan dalam menggilir adalah wajib hukumnya, dihitung dari hari dan jamnya, tidak boleh lebih dari karena mengurangi kesempatan istri yang lain andaikata dia meninggal dalam waktu giliran yang lebih dari itu berarti ia telah durhaka ${ }^{30}$ Tapi jika seorang suami baru menikah lagi dengan gadis, maka dibolehkan baginya untuk menginap selama satu minggu, karena untuk adaptasi dan kalau suami menikah lagi dengan dengan janda maka diberikan toleransi hanya tiga hari. Selanjutnya normal seperti pembagian biasa. Sebagai mana hadis di bawah ini:

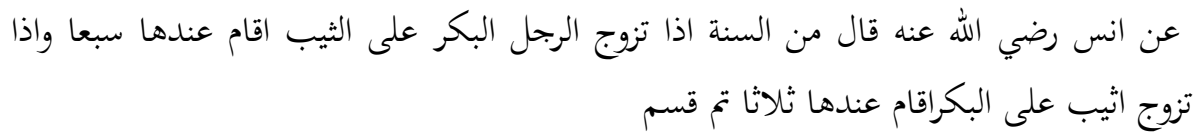

"Dari Anas RA. Sebagian sunnah Nabi ialah apabila seorang lakilaki menikahi seorang gadis sesudah yang janda boleh tingal padanya selama tujuh malam, dan apabila ia mengawini perempuan yang sudah janda boleb ia tetap padanya selama tiga hari dan seterusnya diadakan giliran."

Menurut Abdurrahman Al-Jaziri, Pembagian giliran menjadi sama apabila ada syarat beikut ini:

a. Berakal Sehat

Apabila salah satu diantar istri tersebut dalam keadaan gila maka tidak harus digilir,menunggu sampai Ia tenang dan bias diajak untuk bergaul

b. Istri yang dinikahi haru sudah pubertasi

Bila ada salah satu Istri istri ada yang belum puber maka Ia tidak harus mendapatkan giliran yang sama

c. Tidak durhaka

Apabila istri itu durhaka (melanggar ketentuan yang sudah disepakati dengan suami) maka ia tidak berhak untuk mendapat giliran. ${ }^{31}$

\section{Adil Atas Tempat Tinggal}

Sudah menjadi kewajiban bagi seorang suami untuk memberikan nafkah bagi keluarganya, khususnya istri. salah satu nafkah yang harus

\footnotetext{
29 Syihabudin al-Qalyubi dan Syihabuddin umairah, Qalyubi wa umairah, (Surabaya, alHidayah, tt), 302

${ }^{30}$ Ibnu Masud dan Zaenal abiding ,opcit, 329

31 Abdurrahman al-Jaziri, Opcit, 212-213
} 
dipenuhi adaslah memberikan tempat tinggal yang nyaman. Begitu pula dalam hal poligami seorang suami selain dituntut dalam pembagian waktu gilir juga wajib memberikan tempat berteduh terhadap oara istrinya. Sebagaimana firman Allah surat ath-Thalaq [65] ayat 6

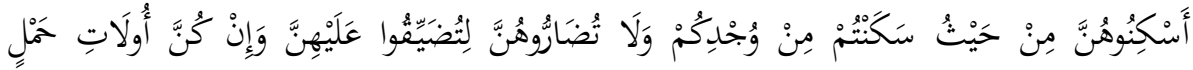

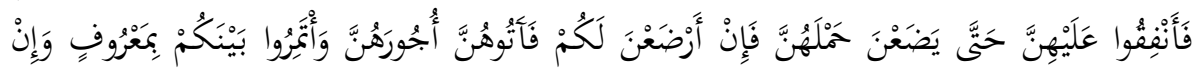

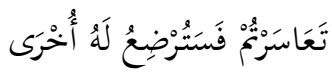

Serta hadis Nabi Muhammad SAW.,

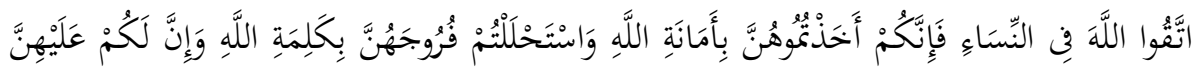

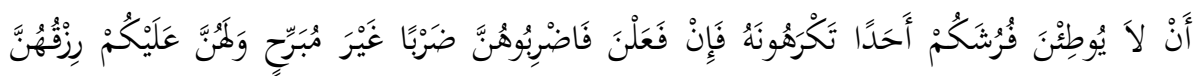

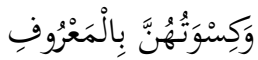

"Takut lab kepada Allah dalam urusan wanita karena sesunggubnya kalian mengambil mereka dengan amanat Allah dan dihalalkan bagi kalian mencampuri mereka dengan kalimat Allah. Akan tetapi Mereka tidak boleh memasukekan seseorang ke tempat tidur kalian yang tidak kalian sukai jika mereka melakukan hal itu, maka pukullah mereka dengan pukulan yang tidak melukai juga diwajibkan atas kalian memberikan nafkah dan pakaian kepada mereka dengan cara yang baik".

Para ulama telah sepakat mengatakan bahwa suami bertanggung jawab menyediakan tempat tinggal yang tersendiri untuk tiap-tiap isteri berserta anak-anaknya sesuai dengan kemampuan suami. Ini dilakukan semata-mata untuk menjaga kesejahteraan isteri isteri, jangan sampai timbul rasa cemburu atau pertengkaran yang tidak diinginkan. Menurut Imam Syafi'i: menggabungkan beberapa istri dalam satu rumah hukumnya haram. ${ }^{32}$

\section{Adil dalam biaya hidup dan pakaian}

Diantara kewajiban seorang suami adalah memberikan nafkah terhadap istri yang meliputi biaya hidup sehar-hari dan biaya pakaian, sebagimana firman allah dalam surat al Baqarah [2]: 233

\footnotetext{
32 Taqyudin Abu Bakar, Opcit, 377.
} 


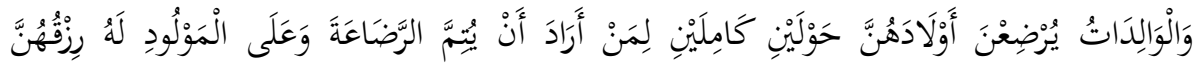

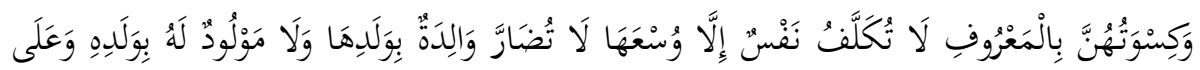

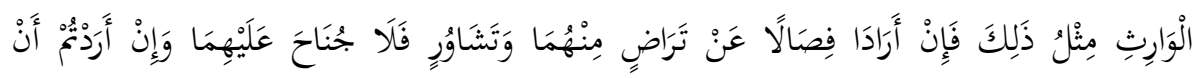

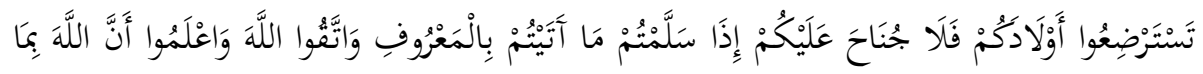

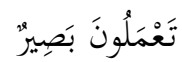
dan Hadis Nabi yang diriwayatkan oleh Tirmidzi

$$
\text { وحقهن عليكم ان تحسنواليهن فن كسوتن وطعامهن }
$$

Dan bak. mereka yang wajib kalian penubi adalah,memperbaiki mereka dari segi pakaian dan makanan. (HR.Tirmidzi)

Syekh Muhammad Qasim al-Ghazi, menerangkan bahwa salah satu kewajiban seorang suami adalah memberikan makanan sebanyak dua mud setiap hari beserta lauk - pauknya, juga peralatan makan dan minum serta peralatan masak, selain itu pula wajib memberikan pakaian yang berlaku dan layak menurut umum, Ibnu katsir,dalam menafsirkan ayat 233 surat al-Baqarah menyatakan sebagai berikut: kewajiban seorang ayah dalam dalam memberikan nafkah dan pakaian terhadap ibu (istri) dengan cara yang baik artinya sesuai dengan yang berlaku menurut kebiasaan masingmasing dengan catatan tidak boros dan tidak kikir. sesuai dengan kemampuannya dan bersikap pertengahan. Yusuf qardlawi berpendapat, bahwa syara' tidak membatasi (tidak menentukan) batas nafkah terhadap istri dengan kadar tertentu,berapa berapa dirham atau berapa rupiah besarnya tapi yang wajib adalah memenuhi secara layak sesuai dengan situasi dan kondisi ${ }^{33}$

\section{Kesimpulan}

Bertindak adil adalah bertindak secara benar. Mencari keadilan sama dengan mencari kebenaran. Kebenaran adalah representasi dari kehendak Tuhan kepada manusia yang dijabarkan melalui al-abkam alkhamsah, yaitu wajib, sunnah, mubah, makruh, dan haram. Keadilan substantif dalam hukum Islam selalu dikaitkan dengan kehendak pembuat syara' (Allah) terhadap manusia, baik kehendak tersebut dipahami melalui deduksi logis (kaedah lughawiyyah), deduksi analogis (qiyas), atau deduksi dari kaedah-kaedah umum syariah (maqasid syari'ab). Dalam kaitannya dengan poligami maka adil adalah sebagai syarat bagi seorang laki-laki untuk melakukan poligami. Menurut penulis ditinjau

\footnotetext{
${ }^{33}$ Iib.uin-malang.ac.id
} 
dari berbagai aspek poligami bukanlah hal yang mudah untuk dilakukan, kecuali mereka yang tidak berpikir akan resiko dari sebuah keputusan berpoligami. Memang Islam tidak melarang atau mengajurkan apalagi memerintah, karena poligami adalah prilaku yang sudah ada sejak zaman jahiliyah tatapi Islam sangat ketat memberikan persyaratan sampai hampir dikatakan tidak boleh, karena dalil yang ada dalam al-Quran, boleh dengan syarat adil tapi disusul dengan ayat lain yang mengatakan bahwa"tidak akan sanggup berlaku adil walaupun berusaha semaksimal mungkin" Walaupun pada akhirnya ulama menyepakati bahwa adil secara kualitatif manusia tidak akan mampu, sehingga pada akhirnya ulama menyepakati adil yang dimaksud adalah batas minimal yang bisa dilakukan berbuat adil, yaitu waktu giliran, nafkah dan tempat tinggal. Menurut Penulis adil sebagai syarat dibolehkannya poligami adalah sebagai syarat mutlak sekaligus peringatan bagi kaum laki-laki agar tidak mudah dan tidak semena-mena melakukan poligami.

\section{DAFTAR PUSTAKA}

Al-Asqalani, Ibnu hajar, Bulughul Maram min Adillat al-Abkam, Jakarta: Dar-al-Kutub al-Islamiyah, 2002.

Al-jaziri Abdurrahman, al-Fiqh a'la Madzahib al-Arba'ah, Beirut: Dar akutub al-Ilmiyah, 1990.

Al-Maraghi, Ahmad Musthafa, Tafsir al-Maraghi, Mesir: Syirkah maktabah wamathba'ah musthafa al-baby al-halabi wa auladihi, juz 4, 1969

Al-Syaukani, Imam Muhammad, Fathu al-qadir jilid 1, Kairo: Dar al-Hadis Angkasa, Filsafat Hukum (Materi Kuliah), Magister Ilmu Hukum Hukum

UNSOED, Perwokerto, 2010.

An-Nawawi, Raudlatu Thalibin, juz 3, tt.

Ansori, Abdul Gafur, Filsafat Hukum Sejarah, Aliran Dan Pemaknaan, Yogyakarta: Gajah Mada Universisty Press, 2006.

Azhary, Muhammad Tahir, Negara Hukum: Suatu Studi tentang Prinsipprinsipnya Dilihat dari Segi Hukum Islam, Implementasinya pada Periode Negara Madinah dan Masa Kini, Jakarta: Bulan Bintang, 1992.

Bakar, Muhammad Taqyuddin Abu, Kifayat al-akhyar fi halli ghayat al ikhtishar, Beirut: Darul khair, 1991.

Fuady, Munir Fuady, Dinamika Teori Hukum, Ciawi-Bogor: Ghalia Indonesia, 2010,

Garvey, James, Karya Filsafat Terbesar, Yogyakarta: Penerbit Kanisius, 2010.

Halim, A. Ridwan, Pengantar Ilmu Hukum Dalam Tanya Jawab, Jakarta:Ghalia Indonesia, 2005. 
Hasan, M. Ali, Pedoman hidup berumah tanngga dalam Islam, Jakarta: siraja perdana media group, 2006. Vol. 2

Huijbers, Theo, Filsafat Hukum dalam Lintasan Sejarah, Yogyakarta: Kanisius, 1993.

Husein Abi qasim, Mu'jam mufradat alfarh al-Quran, Beirut: Dar al-kutub al-ilmiyah, 2004

Ibnu Maskawaih, Tabdhib al-Akblaq wa Tathbir al-'Araq, Mesir: Matba'ah Husayniyyah, $1329 \mathrm{H}$

Kelsen, Hans, Pengantar Teori Hukum, Bandung: Penerbit Nusa Media, 2009.

Khallaf, Abdul Wahhab, Ushul Figh. Beirut: Dar al-Qalam, 1978.

M.Fauzan, Abdul manan, Pokok-pokok Hukum perdata: Wewenang peradilan Agama, Jakarta; Raja grafindo persada, 2002 cet. kelima

Manullang, E. Fernando M, Menggapai Hukum Berkeadilan, Jakarta: Buku Kompas, 2007,

Manzoor, Ahmad, Morality and Law, Karachi: Asia Publishers, 1986.

Masud, Muhammad Khalid, Shatibi's Philoshopy of Islamic Law, Delhi: Adam Publisher, 1997.

Mubarak, Jaih. Modifikasi bukum Islam, Study tentang qaul qadim dan qaul jadid, Jakarta: PT Raja grafindo persada 2002. Cet. kelima

Pusat Bahasa Departemen pendidikan nasional, Kamus besar bahasa Indonesia, balai pustaka, Edisi ke 3, Cet. kelima 2008

Rahardjo, Satjipto, Ilmu Hukum. Bandung: Alumni, 1986.

Ramulyo M.Idris S.H., Beberapa masalah tentang Hukum acara perdata peradilan agama dan bukum perkawinan Islam, Radar jaya offset, Jakarta, tt,

Rato, Dominikus, Filsafat Hukum, Mencari, Menemukan, Dan Memahami Hukum, Surabaya: LaksBang Yustisia, 2010.

Rawls, John, Justice as Fairness: A Restatment, London: Harvard University Press, 2001.

Sabiq, Sayid, Fiqih Sunnah, jilid 3, Kairo: al-fathu li-al I'lam al-arabi, 1992.

Shihab, M. Quraish, Tafsir al-Misbah, Jakarta: lentera hati, volume 2 University Press. 